\title{
HYPERTENSION
}

\section{Role of ACE inhibitors in uncomplicated essential hypertension}

\author{
J I S Robertson
}

The design and early development of drugs which inhibited angiotensin converting enzyme (ACE inhibitors) was conducted with the expectation that the principal applications of such agents would lie in clinical syndromes in which the activity of the renin-angiotensin system was enhanced-for example, renovascular hypertension and certain varieties of cardiac failure. With the introduction of the first orally active ACE inhibitor, captopril, it quickly became apparent, however, that such treatment was applicable to essential (primary) hypertension, in which both the antihypertensive efficacy and the acceptability of ACE inhibitors were found to be at least comparable with those of other drug classes. The use of ACE inhibitors, either given alone or in combination with other drugs, in uncomplicated essential hypertension now constitutes a major indication and has appreciably increased therapeutic freedom. Even so, there remains a remarkable reluctance on the part of some authorities to endorse the use of ACE inhibitors as initial (so-called "first line") treatment in essential hypertension. ${ }^{12}$ I consider this seemingly strange anomaly later in this article.

\section{ACE inhibitors given alone \\ ("monotherapy")}

Even in uncomplicated essential hypertension, circulating plasma concentrations of angiotensin II are within a range in which they exert an immediate, direct effect on arterial pressure. ${ }^{3}$ Thus acute blockade of the renin-angiotensin system, as by infusing an angiotensin II antagonist such as saralasin or by inhibiting ACE, causes an immediate reduction of both arterial pressure and plasma aldosterone, in proportion to the previously prevailing plasma angiotensin II concentration. ${ }^{4}$ In essential hypertension, however, circulating concentrations of renin and angiotensin II are usually modest or low $^{5}$ and decline further with age. Thus the progressive and often eventually distinct antihypertensive effect seen with long term oral administration of an ACE inhibitor was unexpectedly gratifying, not least because it occurred also in elderly subjects.

Given alone, ACE inhibitors are broadly similar in antihypertensive efficacy to a range of other drug classes. ${ }^{6}$ This has been apparent in direct prospective comparisons, including double blind studies.
Table 1 summarises the outcomes of 21 parallel group trials comparing six different ACE inhibitors with placebo, one another, or other antihypertensive agents in essential hypertension. ${ }^{7-28}$

Individual reports have found $\mathrm{ACE}$ inhibitors to be as effective as diuretics, ${ }^{22} \beta$ blockers, ${ }^{24}$ calcium antagonists, ${ }^{29}$ and methyldopa. ${ }^{30}$

In a double blind trial Herrick et al showed enalapril to have a significantly greater antihypertensive effect than atenolol. ${ }^{31}$

Probably because of their effect in slowing heart rate, $\beta$ blockers are liable to have a modest capacity to lower systolic pressure. ${ }^{32} 33$ Systolic blood pressure reduction has, perhaps not surprisingly therefore, been found to be greater with lisinopril than metoprolol ${ }^{24}$ or atenolol. ${ }^{19}$ Even so, enalapril was seen also to lower systolic pressure more than did hydrochlorothiazide. ${ }^{18}$ Conversely, both isradipine ${ }^{34}$ and labetalol ${ }^{35}$ were slightly more effective than enalapril in other studies.

The antihypertensive effect of ACE inhibitors is sustained with long term treatment. ${ }^{6}$ There is little to suggest that their effectiveness is altered with age. ${ }^{33}$

\section{Comparative antihypertensive effect of different ACE inhibitors}

The time of onset and the duration of antihypertensive effect vary considerably between different ACE inhibitors. Table 2 compares data obtained with a range of such agents. $^{36}$

Although the long term antihypertensive potency of different ACE inhibitors is, at currently recommended doses, broadly similar, ${ }^{67}$ some differences may exist. Using ambulatory blood pressure measurement, Conway et al saw a significantly greater reduction in systolic pressure over 24 hours with lisinopril than with enalapril; a similar trend with diastolic pressure was not significant. ${ }^{37}$ But, as Hansson et al have rightly emphasised, ${ }^{6}$ more extensive comparative studies, with a wide range of doses, are needed to clarify this issue.

\section{ACE inhibitors combined with other}

\section{forms of treatment}

DIURETICS

Predictably, the combination of ACE inhibitor with diuretic is particularly effective in 
Table 1 Some parallel group studies comparing ACE inhibitors with other antihypertensive agents in mild to moderate hypertension

\begin{tabular}{|c|c|c|c|c|c|c|c|}
\hline $\begin{array}{l}\text { Reference } \\
\text { No }\end{array}$ & Authors (year) & $\begin{array}{l}\text { No of } \\
\text { patients }\end{array}$ & $\begin{array}{l}\text { Duration } \\
\text { (weeks) }\end{array}$ & $\begin{array}{l}\text { Drug dosage } \\
\text { (mg/day) }\end{array}$ & $\begin{array}{l}\text { Decrease in } \\
\text { blood pressure } \\
\text { (systolic/diastolic) } \\
(\mathrm{mm} \mathrm{Hg})^{\star}\end{array}$ & $\begin{array}{l}\text { Response } \\
\text { rate }(\%) \dagger\end{array}$ & Comments \\
\hline 8 & Andrén et al (1985) & 50 & 8 & $\begin{array}{l}\text { Captopril } \\
\left\{\begin{array}{l}\text { C } 75-300 \\
\text { A } 50-200\end{array}\right.\end{array}$ & $\left.\begin{array}{l}31 / 20 \\
24 / 18\end{array}\right\}$ & & $\begin{array}{l}\text { HCT added in } 30 \\
\text { cases; open study } 2 \\
\text { years }\end{array}$ \\
\hline 9 & $\begin{array}{l}\text { Captopril Research } \\
\text { Group of Japan } \\
(1985)\end{array}$ & 270 & 12 & $\left\{\begin{array}{l}\text { C } 37 \cdot 5-75 \\
\operatorname{Pr} 60-120\end{array}\right.$ & $\left.\begin{array}{l}26 / 15 \\
23 / 12\end{array}\right\}$ & & $\begin{array}{l}\text { TCM added in all } \\
\text { cases; less adverse } \\
\text { effects with } C\end{array}$ \\
\hline 10 & Garinin (1986) & 135 & 16 & $\begin{cases}C & 50-100 \\
\text { E } 10-20\end{cases}$ & $\left.\begin{array}{l}17 / 14 \\
19 / 16\end{array}\right\}$ & & $\begin{array}{l}\text { HCT added in } 26 \\
\text { cases }\end{array}$ \\
\hline 11 & $\begin{array}{l}\text { Rumboldt et al } \\
\text { (1988) }\end{array}$ & 69 & 9 & $\left\{\begin{array}{l}\text { C } 100-200 \\
\text { E } 40-80\end{array}\right.$ & $\begin{array}{l}28 / 21 \\
35 / 25\end{array}$ & $\left.\begin{array}{r}97 \\
100\end{array}\right\}$ & $\begin{array}{l}\text { HCT added in } 53 \\
\text { cases }\end{array}$ \\
\hline 12 & $\begin{array}{l}\text { Witte and Walter } \\
\text { (1987) }\end{array}$ & 222 & 16 & $\begin{cases}C & 200 \\
R & 10\end{cases}$ & $\begin{array}{l}20 / 19 ; 26 / 18 \ddagger \\
22 / 20 ; 28 / 18 \ddagger\end{array}$ & $\left.\begin{array}{l}83 \\
77\end{array}\right\}$ & $\begin{array}{l}\text { HCT added in } 76 \\
\text { cases }\end{array}$ \\
\hline 13 & $\begin{array}{l}\text { Chrysant et al } \\
(1983)\end{array}$ & 31 & 18 & \multirow{6}{*}{$\begin{array}{l}\left\{\begin{array}{l}\text { Enalapril } \\
\text { E } 5-40 \\
\text { Placebo }\end{array}\right\} \\
\left\{\begin{array}{l}\text { E } 20-40 \\
\text { Pr } 160-240\end{array}\right. \\
\left\{\begin{array}{l}\text { E } 20-40 \\
\text { A } 50-100 \\
\text { HCT } 25-50\end{array}\right. \\
\left\{\begin{array}{l}\text { E+ } \\
T+\end{array}\right. \\
\left\{\begin{array}{l}\text { E } 10-40 \\
\text { C } 75-300\end{array}\right. \\
\left\{\begin{array}{l}\text { E 20-40 } \\
\text { HCT 50-100 } \\
\text { E + HCT }\end{array}\right.\end{array}$} & \multirow{6}{*}{ 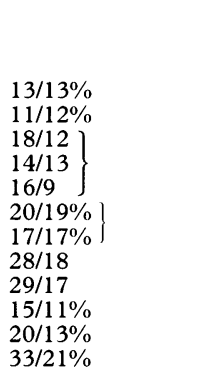 } & & \multirow[t]{2}{*}{$\begin{array}{l}\text { Well tolerated, } \\
\text { effective }\end{array}$} \\
\hline 14 & Goodwin (1984) & 367 & 12 & & & $\begin{array}{l}77 \\
59\end{array}$ & \\
\hline 15 & $\begin{array}{l}\text { Helgeland et al } \\
\quad(1986)\end{array}$ & $436 \$$ & 16 & & & & 10 Week extension \\
\hline 16 & $\begin{array}{l}\text { Sassano et al } \\
(1984)\end{array}$ & 100 & 26 & & & & Hypokalemia with E \\
\hline 17 & Thind et al (1985) & 32 & 16 & & & $\left.\begin{array}{l}75 \\
75\end{array}\right]$ & \multirow[t]{2}{*}{ HCT 50 added to all } \\
\hline 18 & Vidt (1984) & 455 & 8 & & & $\left.\begin{array}{l}22 \\
42 \\
80\end{array}\right\}$ & \\
\hline 19 & $\begin{array}{l}\text { Bolzano et al } \\
\quad(1987)\end{array}$ & 490 & 24 & \multirow{6}{*}{ 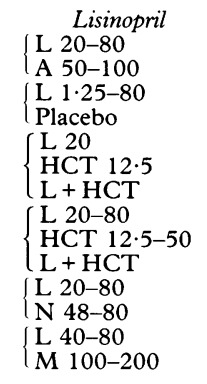 } & \multirow{2}{*}{$\begin{array}{l}89 \\
87 \\
16 / 10\end{array}$} & \multirow{6}{*}{$\begin{array}{l}82 \\
67 \\
84 \\
82 \\
79 \\
63 \\
65\end{array}$} & \multirow{6}{*}{$\begin{array}{l}8 \cdot 2 \% \text { Stopped by } \\
\text { adverse effects }\end{array}$} \\
\hline 20 & Gomez et al (1985) & 102 & 6 & & & & \\
\hline 21 & Merrill et al (1987) & 207 & 8 & & $\begin{array}{r}9 \cdot 2 \% \\
6 \cdot 4 \% \\
15 \cdot 7 \%\end{array}$ & & \\
\hline 22 & Pool et al (1987) & 394 & 24 & & & & \\
\hline 23 & Morlin et al (1987) & 136 & 12 & & & & \\
\hline 24 & $\begin{array}{l}\text { Zachariah et al } \\
\quad(1987)\end{array}$ & 175 & 8 & & & & \\
\hline 25 & $\begin{array}{l}\text { Karlberg et al } \\
\text { (1987) }\end{array}$ & 34 & 4 & \multirow{2}{*}{$\begin{array}{l}\quad \text { Ramipril } \\
\left\{\begin{array}{l}\text { R } 5-10 \\
\text { Placebo }\end{array}\right. \\
\left\{\begin{array}{l}\text { R } 2 \cdot 5-5 \\
\text { Placebo }\end{array}\right.\end{array}$} & $22 / 9$ & & \\
\hline 26 & $\begin{array}{l}\text { Villamil et al } \\
\quad(1987)\end{array}$ & 86 & 4 & & $15 / 18$ & & $\begin{array}{l}19 \text { Patients dropped } \\
\text { out }\end{array}$ \\
\hline 27 & Morgan et al (1987) & 32 & 4 & $\begin{array}{l}\text { Perindopril } \\
\text { Pe } 2-8 \\
\text { Placebo }\end{array}$ & $\left.\begin{array}{l}22 / 11 \\
3 / 2\end{array}\right\}$ & & $\begin{array}{l}\text { Effects of Pe were } \\
\text { independent of } \\
\text { sodium intake }\end{array}$ \\
\hline \multicolumn{8}{|c|}{ Quinapril } \\
\hline 28 & Gavras (1984) & 8 & 1 & Q $0.625-10$ & $27 / 26$ & & \\
\hline
\end{tabular}

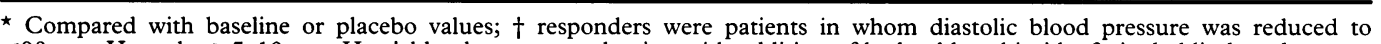
$\leqslant 90 \mathrm{~mm} \mathrm{Hg}$ or by $\geqslant 5-10 \mathrm{~mm} \mathrm{Hg} ; \ddagger$ blood pressure reduction with addition of hydrochlorothiazide; $\$$ single blind study. A, atenolol; HCT, hydrochlorothiazide; E+, E + HCT + oxprenolol + dihydralazine; M, metoprolol; N, nifedipine; Pr, propranolol; T+, HCT + oxprenolol + dihydralazine; TCM, trichlormethiazide.

Table 2 Relation between time and effect for some ACE inhibitors. ${ }^{36}$ Time is in hours

\begin{tabular}{lllccc}
\hline & Captopril & Enalapril & Lisinopril & Ramipril & Cilazapril \\
\hline Time to peak blood concentration & 1 & 3 & 7 & $2 \cdot 5$ & 2 \\
$\begin{array}{l}\text { Hypotensive response to single dose: } \\
\text { Onset }\end{array}$ & $0 \cdot 5$ & $1-1 \cdot 5$ & 2 & 2 & 1 \\
Time to maximal effect & 1 & 4 & 6 & 4 & 6 \\
Duration of effect & $4-6$ & $8-12$ & 18 & 18 & 10 \\
\hline
\end{tabular}

lowering arterial pressure. Diuretics increase circulating concentrations of angiotensin II, and this limits their antihypertensive effect. ${ }^{\circ}$ Thus giving an ACE inhibitor with a diuretic prevents the rise in angiotensin II concentration and clearly enhances efficacy. Indeed, hypertension is adequately controlled in more than $80 \%$ of patients when these two classes of drug are given together. ${ }^{38}$ Alternatively, the introduction of an ACE inhibitor can allow the dose of thiazide to be lowered. ${ }^{39}$
The combination of ACE inhibitor with a loop acting diuretic is valuable in controlling previously unresponsive hypertension. ${ }^{4041}$ ACE inhibitors, by lowering plasma angiotensin II concentration, diminish aldosterone secretion and so minimise ${ }^{6}$ the potassium depletion and hypokalaemia which otherwise accompany the use of thiazides or loop acting diuretics. $^{42}$ An important corollary is that potassium sparing diuretics such as amiloride, triamterene, and spironolactone are usually 
unnecessary in this combination; indeed, in patients with renal impairment, which may be occult in elderly subjects, dangerous hyperkalaemia might be provoked by their use. A further theoretical gain with the addition of ACE inhibitor to thiazide or loop acting diuretic is that raised plasma potassium concentrations could enhance the antihypertensive effect. ${ }^{43}$ Additional bonuses are that the potentially adverse effects of thiazides on plasma lipids, uric acid, and glucose are lessened. ${ }^{64}$

\section{DIETARY SALT RESTRICTION}

Dietary salt restriction, like diuretic use, raises plasma angiotensin II concentration, ${ }^{45}$ which thus, for similar reasons, inhibits the antihypertensive effect. Again and predictably, the addition of ACE inhibitor enhances the reduction in blood pressure. ${ }^{46}$

\section{$\beta$ ADRENERGIC BLOCKADE}

One of the actions of $\beta$ blocking drugs is inhibition of renin secretion and hence the lowering of plasma angiotensin II concentration. ${ }^{47}$ Although the importance of this action as a contributor to the blood pressure reduction seen with $\beta$ adrenergic blockade has been disputed, ${ }^{47}$ it will be apparent that ACE inhibitors and $\beta$ blockers share this mode of action. Thus it might be that the combination of these two classes of agent would be relatively ineffective. The clinical evidence is, however, conflicting.

Wing et al found the combination of enalapril with atenolol to be largely ineffective. $^{48}$ Similarly, although MacGregor et al found that the addition of either nifedipine or hydrochlorothiazide to captopril was useful, no further fall in blood pressure occurred with the addition of propranolol to captopril. ${ }^{49}$

By contrast, Staessen et al found a similar additional antihypertensive effect with either propranolol or thiazide given with pre-existing captopril. $^{50}$ Similarly, Belz et al observed a worthwhile further reduction in blood pressure when cilazapril and propranolol were combined. ${ }^{51}$

The age of the patients studied might partially explain some of these seemingly discrepant reports. ${ }^{62}$ Plasma renin declines with age,${ }^{5}$ hence differing effects might be seen according to age. The addition of lisinopril to atenolol caused a $56 \%$ greater fall in diastolic pressure in patients under 50 compared with those of 50 and over. ${ }^{52}$

DIURETIC PLUS $\beta$ BLOCKER PLUS ACE INHIBITOR

Examining a range of drugs added to the treatment of patients whose blood pressure was inadequately controlled by thiazide plus $\beta$ blocker, Bevan et al found captopril to be more effective than nifedipine or hydralazine. ${ }^{53}$ When these results were combined with those from an earlier trial of identical design from the same centre, ${ }^{54}$ captopril was the most effective third drug in comparison with methyldopa, prazosin, hydralazine, and nifedipine. All the third drugs did better than placebo. In this context, considering acceptability as well as efficacy, captopril was evidently the most suitable third drug.

$\alpha$ ADRENERGIC BLOCKADE

The combination of either captopril or enalapril with doxazosin has been reported to be both effective and well tolerated. ${ }^{55}$

\section{KETANSERIN}

Studies combining either captopril ${ }^{56}$ or enalapril $^{57}$ with ketanserin, an antagonist of serotonin type 2 receptors and $\alpha_{1}$ adrenergic receptors, have shown particularly good antihypertensive efficacy. When ketanserin and captopril were given together the combined blood pressure lowering was more than twice that of either drug given alone. ${ }^{56}$

TYPE 2 CALCIUM ANTAGONISTS

The combination of a type 2 calcium antagonist (dihydropyridine) with ACE inhibition is especially effective. ${ }^{58-60}$ Moreover, because ACE inhibition can reduce the tachycardia, headache, and pedal oedema induced by calcium antagonists, tolerance of calcium antagonists is improved. ${ }^{60}$

\section{Mechanism of antihypertensive effect of ACE inhibitors}

The necessarily appropriate acknowledgement that the mechanism or mechanisms of the antihypertensive action of ACE inhibitors is imperfectly understood is to recognise a similarity with other widely used drug classes such as thiazides and $\beta$ blockers, for which, likewise, the mode of action remains partly obscure.

The immediate effect of the administration of ACE inhibitor is a reduction in peripheral plasma angiotensin II concentration, with a proportionate acute fall in blood pressure. With continued administration of an ACE inhibitor, however, a further substantial fall in arterial pressure usually occurs in essential hypertension. Several mechanisms have been proposed to explain this progressive antihypertensive effect. These are not mutually exclusive; all are currently speculative.

The existence of numerous local tissue renin-angiotensin systems is well established. Inhibition of these might, in several ways, contribute to lowering of arterial pressure. Among these, an especially attractive theory is that ACE inhibition reverses the broadly "trophic" action of angiotensin II on the medial smooth muscle of resistance arteries; reversal of this trophic effect causes regression of the medial thickening, and hence enhancement of blood pressure reduction. ${ }^{61}$ Recent evidence suggests that medial thickening in resistance arteries in hypertension is achieved by rearrangement of smooth muscle cells and not by either their hypertrophy or hyperplasia. This newer knowledge requires some readjustment of concepts. ${ }^{61}$

The effects achieved via modification of endothelial function are considered in this supplement by Drexler. ${ }^{62}$ 
Inhibition of the formation of angiotensin II, both within the circulation and locally in the brain, will diminish sympathetic nervous discharge. ${ }^{63}$ Such an effect has been clearly shown in certain clinical circumstances, notably cardiac failure. ${ }^{64}{ }^{65} \mathrm{~A}$ similar action should contribute to blood pressure reduction in essential hypertension.

Diminution of circulating concentrations of angiotensin II lowers the rate of aldosterone secretion. Among the consequences of this is raised plasma potassium concentration, which is likely to contribute, albeit modestly, to the antihypertensive effect. ${ }^{43}$

Another consequence of a reduction in aldosterone secretion is promotion of natriuresis. Long term use of ACE inhibitors alone lowers exchangeable body sodium in patients with renal artery stenosis. ${ }^{66}$ Whether a similar effect obtains in essential hypertension is unknown, although the noticeable additional antihypertensive effect when ACE inhibitors are combined with diuretics or salt restriction (see above) indicates that in these circumstances it is at most modest.

Angiotensin converting enzyme is identical with kininase II, the enzyme responsible for degradation of kinins. Thus ACE inhibition should lead to the accumulation of vasodilator kinins in the circulation or various other tissues, or both. ${ }^{36}$ To what extent any such effects contribute to the blood pressure reduction remains uncertain.

\section{Possible ancillary benefits}

In recent years increasing attention has been directed at the possible benefits of some classes of antihypertensive drug in addition to their capacity to lower arterial pressure. These approaches might enhance the so far limited (albeit distinct) achievements of antihypertensive treatment in reducing morbidity related to hypertension. ${ }^{67}$ Especially promising approaches have been directed towards the limitation of myocardial ischaemia and to minimising the development of atheroma.

One avenue is to use antihypertensive drugs that can also reverse left ventricular hypertrophy. The limitations of retrospective analyses in the evaluation of the comparative efficacy of different drug classes in correcting left ventricular hypertrophy are illustrated by the different results obtained in three such major surveys. ${ }^{68-70}$ Specifically designed prospective trials are likely to be more revealing. These matters are discussed in detail in this supplement by Richards et al. ${ }^{71}$

A second approach is to improve the compliance of large arteries in hypertension. Diminished compliance is accompanied by a disproportionate increase in systolic pressure, increased turbulence of blood flow, and predisposition to the formation of atheroma ${ }^{67}$ Several clinical trials have indicated that ACE inhibitors are effective-and more effective than some other classes of drug - in improving the compliance and distensibility of large arteries in hypertension. ${ }^{72}$

A third approach is to use antihypertensive drugs that could limit endothelial damage and preserve the beneficial biochemical, biophysical, and physiological properties of vascular endothelium. These aspects are discussed further by Drexler in this supplement. ${ }^{62}$

The vexed question of whether modestly raised plasma renin, and hence raised angiotensin II concentrations, carries a specific adverse prognosis in essential hypertension remains unresolved. (Undoubtedly, markedly raised plasma concentrations of angiotensin II can cause myocardial necrotic lesions, arterial damage, and renal tubular necrosis. ${ }^{73}$ ) The original proposal, that modestly raised plasma renin activity in essential hypertension predisposes to stroke and myocardial infarction, has been abandoned. In a later prospective study, Alderman et al found that hypertensive subjects with raised plasma renin activity were more likely than those with lower renin activities to suffer myocardial infarction, but not stroke. ${ }^{74}$ The analysis was, however, based on few events and was not confirmed by the large study of Meade et al. ${ }^{75}$ Most relevant is that the results were insufficiently impressive to deter Alderman from subsequently advocating thiazide diuretics, which raise plasma renin and angiotensin II values, as first treatment in hypertension. ${ }^{76}$ Thus these aspects cannot at present be convincingly invoked in favour of the early use of ACE inhibitors in essential hypertension.

\section{Quality of life}

Early open studies, in which ACE inhibitors were given to patients with poorly controlled hypertension, raised the possibility, not wholly welcome, that these drugs might possess a euphoriant effect, ${ }^{77}$ perhaps because of central inhibition of enkephalinase. Closer critical evaluation suggested, however, that a more likely explanation was that the ACE inhibitor was giving relief from the unpleasant symptoms associated with other drugs.

\section{RESULTS OF STUDIES}

In a double blind study Callender et al found a slight but significant depression of mood when captopril was substituted for placebo. ${ }^{78}$ Dahlöf et al observed that in patients with essential hypertension measures of wellbeing increased when placebo was substituted for previous diuretic and $\beta$ blocker treatment and remained significantly better when enalapril was introduced. ${ }^{79}$ Olajide and Lader found neither enalapril nor placebo to have measurable effect on mood in normal volunteers. ${ }^{80}$ Lichter et al observed a slight but significant impairment of memory on treatment with atenolol but not with enalapril in essential hypertension. ${ }^{81}$ In a large trial in men with essential hypertension captopril was more acceptable than either methyldopa or propranolol in several measures of quality of life. ${ }^{30}$ Lisinopril was compared with nifedipine over 10 weeks in 828 patients with essential hypertension. Only at the highest dose $(80 \mathrm{mg})$ of nifedipine was wellbeing impaired. ${ }^{82}$

The superiority of ACE inhibitors was not 
confirmed in a range of studies comparing them with more modern drugs. No major differences were found when atenolol was evaluated against enalapril, ${ }^{31} 83$ captopril, ${ }^{83} 84$ and delapril hydrochloride. ${ }^{6}$ In a controversial report by Testa et al captopril was more acceptable than enalapril. ${ }^{85}$ This study has been both severely criticised ${ }^{86-88}$ and defended. ${ }^{89}$

CONCLUSION

ACE inhibitors do not usually have major adverse effects on the quality of life. They seem to be distinctly superior to methyldopa and propranolol and probably also nifedipine. There is no good evidence of long term superiority over atenolol. A suggestion that captopril is more acceptable than enalapril has been questioned. ACE inhibitors do not have a euphoriant effect. There is no good evidence that ACE inhibitors cause sexual problems.

\section{Side effects}

As Fletcher and Dollery have emphasised, ${ }^{77}$ side effects associated with ACE inhibitors can be placed into four principal groups: effects related to the main pharmacological action (hypotension, bradycardia, renal impairment); effects connected with subsidiary actions (enhancement of kinins, inhibition of enkephalinase); idiosyncratic class effects (cough, angioneurotic oedema, Raynaud's phenomenon); and compound specific (mainly captopril) effects (proteinuria, the nephrotic syndrome, taste disturbance, rash, and perhaps Guillain-Barré neuropathy).

\section{FIRST DOSE HYPOTENSION}

ACE inhibition will cause an initial acute fall in arterial pressure, in proportion to the prevailing peripheral plasma concentration of angiotensin II. This is unlikely to cause problems with the introduction of an ACE inhibitor in previously untreated essential hypertension, when plasma renin and hence angiotensin II concentration are likely to be normal or low. Caution is needed if previous treatment, such as diuretics, has raised angiotensin II concentrations. Severe first dose hypotension, endangering cerebral and renal blood flow, can readily occur in these circumstances. $^{90}$ Whenever possible, such antecedent treatment should be withdrawn for a few days before starting ACE inhibition. Otherwise, the ACE inhibitor should be introduced under strict supervision, with facilities (such as angiotensin II for infusion) available for resuscitation as necessary.

First dose hypotension is not necessarily a sole consequence of acute loss of the arterial constrictor effect of angiotensin II. Contributions may also come from loss of angiotensin mediated sympathetic enhancement and vagal inhibition, when bradycardia can be an added hazard. However, these additional problems (which may call for the administration of atropine) are more likely in heart failure treated by diuretics and digoxin than in essential hypertension. ${ }^{91}$
First dose hypotension has also been asserted to occur independently of the prevailing angiotensin II concentration in elderly subjects with essential hypertension, although this is not well substantiated. Elderly subjects are, nevertheless, likely to tolerate hypotension poorly.

RENAL IMPAIRMENT

Renal functional deterioration is not likely with the use of ACE inhibitors in uncomplicated essential hypertension. More usually it stems from loss of angiotensin II mediated sustenance of renal function in circumstances of impaired renal blood flowfor example, cardiac failure or renal artery stenosis. $^{92}$ Occult renal artery stenosis in patients with apparent essential hypertension can cause problems; it is more prevalent in elderly subjects and in those with evident arterial disease at other sites.

HYPERKALAEMIA

Hyperkalaemia occurs with ACE inhibitors only if they are given incorrectly, with potassium conserving agents, or to patients with renal impairment.

SINUS TACHYCARDIA

Sinus tachycardia, which can persist, is an unusual, but real, problem, most often occurring with concomitant diuretic and ACE inhibition. ${ }^{93}$

\section{COUGH}

That ACE inhibitors can provoke dry cough has been known since the paper of Havelka et al in 1982. ${ }^{94}$ The reported prevalence of this side effect varies widely, from less than $1 \%$ up to $22 \% .{ }^{77}$ The problem seems common to all currently used clinical ACE inhibitors.

The cough is associated with increased sensitivity of the cough reflex. Some, but not all, asthmatic subjects seem to be especially susceptible. Although the mechanism is not known, an increase in tissue kinin may be contributory.

\section{ANGIONEUROTIC OEDEMA}

Angioneurotic oedema, which can affect the lips, tongue, glottis, mouth, or larynx, can be life threatening. It affects some $0.2 \%$ of patients and seems to be independent of the individual ACE inhibitor used. Most cases occur in the first week of treatment, and these are potentially the most serious. ${ }^{77}$

With angioneurotic oedema ACE inhibition should be stopped. Most instances resolve spontaneously; there has been a suggestion that addition of antihistamines can be helpful.

If the tongue, glottis, or larynx are affected to an extent that the airways are obstructed subcutaneous adrenaline solution (1:1000 (3-5 $\mathrm{ml})$ ) should be given at once.

RAYNAUD'S PHENOMENON

Raynaud's phenomenon is an unusual complication of both captopril and enalapril treatment. $^{95}$ In one double blind trial 
comparing enalapril with atenolol, enalapril induced Raynaud's phenomenon was sufficiently severe in one patient to cause the drug to be withdrawn ${ }^{31}$; no patient taking atenolol encountered this problem.

It is probable that because of the supposed unlikelihood of this side effect (ACE inhibitors have been tried as treatment for Raynaud's phenomenon) it has been misattributed and hence under-reported. ${ }^{95}$

GUILLAIN-BARRÉ NEUROPATHY

Rare cases have been described of GuillainBarré neuropathy as a complication of captopril treatment. ${ }^{77}$ In one instance it was seen at a dose of only $75 \mathrm{mg}$ daily. There is one report of peripheral neuropathy in association with enalapril. ${ }^{96}$

\section{RASH}

Rash, usually maculopapular and with accompanying pruritis, was common with captopril treatment when high doses were used; it is much less common with the lower doses currently given. ${ }^{77} \mathrm{ACE}$ inhibitors other than captopril do not seem to be associated with rash more often than are other antihypertensive agents. ${ }^{77}$

\section{TASTE DISTURBANCE}

Taste disturbance, like rash, was commonly reported in the early days of captopril treatment, when large doses were used. The problem was attributed to the zinc binding properties of the sulphydryl group in the captopril molecule.

The side effect has receded with the use of more modest doses of captopril and now occurs no more frequently than with other ACE inhibitors such as enalapril. ${ }^{77}$

PROTEINURIA: THE NEPHROTIC SYNDROME Another problem attributable to former large doses of captopril, and seemingly due to the sulphydryl group, was proteinuria, with occasional frank cases of the nephrotic syndrome. ${ }^{97}$ In one patient the nephrotic syndrome occurred with high doses of captopril and resolved when enalapril was substituted. ${ }^{98}$

Such severe proteinuria is no longer encountered with the lower doses of captopril now used.

\section{NEUTROPENIA}

Neutropenia was associated with high doses of captopril and was thought to be a consequence of the sulphydryl moiety. It is no longer a problem with current lower doses. ${ }^{77}$

\section{Hypertension in pregnancy}

ACE inhibition in pregnant animals has been associated with fetal loss. Although controlled data are elusive for human pregnancy, intrauterine growth retardation, fetal abnormalities, oligohydramnios, and anuria and hypotension in the newborn have been reported. ${ }^{699} \mathrm{ACE}$ inhibitors are therefore not recommended for pregnant women with essential hypertension.

\section{Hypertension in children and adolescents}

ACE inhibitors are useful in treating essential hypertension in children and adolescents. ${ }^{6}$ Because of the previously mentioned hazards of ACE inhibition in pregnant women, especial caution is needed when treating girls of reproductive age.

\section{Antihypertensive doses of ACE inhibitors}

As I have already said, doses of ACE inhibitors used in treating essential hypertension were formerly unnecessarily large. In the case of captopril in particular these high doses were accompanied by various unwanted effects, some of which were serious. With the lower doses now used the side effect burden has lightened substantially. The recommended oral doses of some currently available ACE inhibitors in the treatment of essential hypertension are as follows. ${ }^{100}$

Captopril-The usual starting dose is $12.5 \mathrm{mg}$ twice or thrice daily. This is lowered to an initial dose of $6.25 \mathrm{mg}$ in subjects likely to suffer first dose hypotension. The maximum recommended total daily dose is $150 \mathrm{mg}$ -that is, $75 \mathrm{mg}$ twice daily or $50 \mathrm{mg}$ thrice daily. Doses are lower in renal impairment.

Cilazapril-The initial dose is $1 \mathrm{mg}$ once daily, increasing to a maximum of $5 \mathrm{mg}$ once daily. Dosage should be reduced in renal impairment.

Enalapril-The initial dose is $2.5 \mathrm{mg}$ or $5 \mathrm{mg}$ once daily, increasing to a usual maintenance dose of $10-20 \mathrm{mg}$ once daily. The maximum recommended dose is $40 \mathrm{mg}$ once daily. Lower doses are needed in renal impairment.

Lisinopril-The initial dose is $2.5 \mathrm{mg}$ once daily, increasing to a usual maintenance dose of $10-20 \mathrm{mg}$ once daily. The maximum recommended dose is $40 \mathrm{mg}$ once daily. Lower doses are recommended with renal impairment.

Perindopril-The initial dose of $2 \mathrm{mg}$ once daily can be increased to a maximum of $8 \mathrm{mg}$ once daily. Doses are lower in renal impairment.

Quinapril-An initial dose of $10 \mathrm{mg}$ once daily can be titrated by doubling to a maximum of $80 \mathrm{mg}$ daily. The usual maintenance dose is $20-40 \mathrm{mg}$ once daily. Lower doses are given in renal impairment.

Ramipril-The initial dose is $1.25 \mathrm{mg}$ once daily, increasing to a usual maintenance dose of $2 \cdot 5-5 \mathrm{mg}$ once daily. The maximum dose is $10 \mathrm{mg}$ once daily. Doses are lower in renal impairment.

\section{Place of ACE inhibitors in the} antihypertensive repertoire

The data I have summarised indicate that ACE inhibitors are a valuable addition to the therapeutic repertoire in essential hypertension. Though some of their properties may confer benefits additional to those stemming from blood pressure reduction alone, this 
remains to be assessed, and substantiated or denied, in future trials. ${ }^{6}$

The most recent treatment guidelines issued by the World Health Organisation and International Society of Hypertension recommend that ACE inhibitors are used as initial treatment in essential hypertension. ${ }^{101}$ The 1993 USA Joint Committee, ${ }^{1}$ reversing an earlier view, does not, while the British Hypertension Society was unable to reach consensus on this point. ${ }^{2}$ The arguments advanced against accepting ACE inhibitors as initial treatment are not models of lucid rational thought: in several respects they exemplify well the problems of attempting to propagate science by committee, a procedure previously much derided. ${ }^{102} 103$

For example, the American and British committees erroneously state that only diuretics and $\beta$ blockers have been adequately tested in major trials of antihypertensive treatment. ${ }^{1}$ Whereas debate may be centred on what constitutes a major trial, a very wide range of other drugs has been included in studies showing benefit from antihypertensive treatment. This range includes guanethidine, reserpine, methyldopa (extensively), clonidine, hydralazine (extensively), and nifedipine. ${ }^{104}$ The available evidence suggests that blood pressure reduction in itself is accompanied by benefit; thus if ACE inhibitors lower blood pressure safely-and I have reviewed the substantial information in this article-they merit appropriate use. These concepts do not of course exclude the possibility of important additional benefits deriving from drug properties ancillary to blood pressure reduction. ${ }^{67104}$ Any such benefits nevertheless require critical evaluation.

Even more remarkable is that all three committees ${ }^{12} 101$ recommend non-pharmaceutical measures both to precede and to accompany drug treatment. This is even though it is also conceded, correctly, that no therapeutic benefit has been shown for such non-pharmaceutical measures.

Non-pharmaceutical approaches are, unlike ACE inhibitors, apparently regarded by the committees as safe. Some others are more wary. For example, the safety of dietary salt restriction has been seriously questioned. ${ }^{105-107}$ Although disputed, ${ }^{108}$ this issue, like others concerning non-pharmacological measures, remains untested. Moreover, all three committees recommend, without qualification, dietary attempts to lower serum cholesterol concentration despite the fact that two large trials have shown that hypertensive subjects over the age of 60 have a better prognosis the higher their serum cholesterol concentration. ${ }^{109} 110$

I am unimpressed by the inconsistent, sometimes contrary, and often unsubstantiated arguments advanced by these committees. ${ }^{104} \mathrm{~A}$ more reasonable conclusion is that ACE inhibitors are a valuable, if still imperfect, addition to the therapeutic repertoire in essential hypertension. There are no evident reasons for undue reluctance about their early introduction.
1 Joint National Committee on the Detection, Evaluation, and Treatment of High Blood Pressure (JNC V). Fifth report. Arch Intern Med 1993;153:154-83.

2 Sever P, Beevers G, Bulpitt C, et al. Management guidelines in essential hypertension: report of the second working party of the British Hypertension Society. $B M 7$ 1993;306:983-7.

3 Chinn RH, Düsterdieck G. The response of blood pressure to infusion of angiotensin II: relation to plasma concentrations of renin and angiotensin II. Clin $S c i$ 1972;42:489-504.

4 Brown JJ, Brown WCB, Fraser R, et al. The effects of the angiotensin II antagonist saralasin on blood pressure and plasma aldosterone in man in relation to the prevailing plasma angiotensin II concentration. Prog prevailing plasma angiotensin II

5 Swales JD. The renin-angiotensin system in essential hypertension. In: Robertson JIS, Nicholls MG, eds. The renin-angiotensin system. Vol 2. London: Gower, 1993: 62.1-12.

6 Hansson L, Dahlöf B, Himmelman A, Svensson A Angiotensin-converting enzyme inhibitors in the treatment of essential hypertension. In: Robertson JIS Nicholls MG, eds. The renin-angiotensin system. Vol 2. London: Gower, 1993:91.1-24.

7 McAreavey D, Robertson JIS. Angiotensin converting enzyme inhibitors and moderate hypertension. Drugs 1990;40:326-45.

8 Andrén L, Karlberg BE, Svensson A, et al. Long-term effects of captopril and atenolol in essential hypertension. Acta Med Scand 1985;217:155-60.

9 Captopril Research Group of Japan. Clinical effects of low-dose captopril plus a thiazide diuretic on mild to moderate essential hypertension: a multicenter doubleblind comparison with propranolol. 7 Cardiovasc Phar macol 1985;7(suppl 1):77-81.

10 Garinin G. A comparison of once-daily antihypertensive therapy with captopril and enalapril. Curr Ther Res 1986;40:567-75.

11 Rumboldt Z, Marinkovic M, Drinovic J. Enalapril versus captopril: a double-blind multicentre comparison in essential hypertension. Int $\mathcal{f}$ Clin Pharmacol Res 1988 ; 8:181-8.

12 Witte PU, Walter U. The multicenter study group: comparative double-blind study of ramipril and captopril in mild to moderate essential hypertension. $A m$ f pril in mild to moderate esse

13 Chrysant SG, Brown RD, Kem DC, Brown J Antihypertensive and metabolic effects of a new converting enzyme inhibitor, enalapril. Clin Pharmacol Ther 1983;33:741-6.

14 Goodwin FJ. A comparative study of enalapril and propranolol in mild to moderate essential hyper tension. Symposium on the management of congestive hear failure and hypertension. London: 1984. (Abstract No L-17.)

15 Helgeland A, Hagelind $\mathrm{CH}$, Strommen R, Tretli S Enalapril, atenolol, and hydrochlorothiazide in mild to moderate hypertension. Lancet 1986; i:872-5.

16 Sassano P, Chatellier G, Amiot AM, et al. A double-blind randomized evaluation of converting enzyme inhibition as the first treatment of mild to moderate hypertension. f Hypertens 1984;2(suppl 2):75-80.

17 Thind GS, Johnson A, Bhatnagar D, Herkel TW. A parallel study of enalapril and captopril and one year of experience with enalapril in moderate-to-severe hypertension. Am Heart f 1985;109:852-8.

18 Vidt DG. A controlled multiclinic study to compare the antihypertensive effects of MK-421, hydrochlorothiazide, and MK-421 combined with hydrochlorothiazide in patients with mild to moderate essential hypertension. in patients with mild to moderate

19 Bolzano K, Arriaga J, Bernal R, et al. The antihypertensive effect of lisinopril compared to atenolol in patients with mild to moderate hypertension. $f$ Cardiovasc Pharmacol 1987;9(suppl 3):43-7.

20 Gomez HJ, Stromovsky MS, Kristianson K, et al. Lisinopril dose in mild to moderate hypertension. Clin Pharmacol Ther 1985;37:198.

21 Merrill DD, Byyny RL, Carr A, et al. Lisinopril/ hydrochlorothiazide in essential hypertension. Clin Pharmacol Ther 1987;41:227.

22 Pool JS, Gennari J, Goldstein R, et al. Controlled multicenter study of the antihypertensive effects of lisinopril, hydrochlorothiazide, and lisinopril plus hydrochlorothiazide in the treatment of 394 patients with mild to moderate essential hypertension. 7 Cardiovasc Pharmacol 1987;9(suppl 3):36-42.

23 Morlin C, Baglivo $\mathrm{H}$, Boeijinga $\mathrm{JK}$, et al. Comparative trial of lisinopril and nifedipine in mild to severe essential hypertension. 7 Cardiovasc Pharmacol 1987, 9(suppl 3):48-52.

24 Zachariah PK, Bonnet G, Chrysant SG, et al. Evaluation of antihypertensive efficacy of lisinopril compared to metoprolol in moderate to severe hypertension. $f$ Cardiovasc Pharmacol 1987;9(suppl 3):53-8.

25 Karlberg BE, Lindstrom T, Rosenqvist R, et al. Efficacy, tolerance, and hormonal effects of a new oral 498), in mild to moderate primary hypertension. $A m \mathcal{F}$ 498), in mild to moderate
Cardiol 1987;59:104-9 D.

26 Villamil AS, Cairns V, Witte PU, Bertolasi C. A doubleblind study to compare the efficacy, tolerance and safety of two doses of the angiotensin converting enzyme 
inhibitor ramipril with placebo. Am f Cardiol 1987; 59:110-4 D.

27 Morgan T, Anderson A, Wilson D, et al. The effect of perindopril on blood pressure in humans on different sodium intakes. I Cardiovasc Pharmacol 1987;10(suppl 7):119-21.

28 Gavras I. Pilot study of the effects of the angiotensin converting enzyme inhibitor CI-906 on patients with essential hypertension. If Clin Pharmacol 1984;24: 343-50.

29 Witchitz S, Serradimigni A. Lisinopril versus slow-release nifedipine in the treatment of mild-to-moderate nifedipine in the treatment of mild-to-moderate
essential hypertension. $f$ Hum Hypertens 1989;3 (suppl 1):29-33.

30 Croog SH, Levine S, Testa MA, et al. The effects of antihypertensive therapy on the quality of life. $N$ Engl $f$ Med 1986;314:1657-64.

31 Herrick AL, Waller PC, Berkin KE, et al. Comparison of enalapril and atenolol in mild to moderate hypertension. Am F Med 1989:86:421-6.

32 Ball SG. Systolic hypertension: a comparison of the trials with enalapril and beta-antagonists. Current Opinion in Cardiology 1987;2(suppl 1):33-8.

33 Ball SG. Age-related effects of converting enzyme inhibitors: a commentary. $f$ Cardiovasc Pharmacol 1988;12(suppl 8):105-7.

34 Eisner GM, Johnson BF, MacMahon P, et al. A multicenter comparison of the safety and efficacy of isradipine and enalapril in the treatment of hypertension. Am f Hypertens 1991;4(suppl):154-7.

35 Applegate WB, Borhani N, De Quattro V, et al. Comparison of labetalol versus enalapril as monotherapy in elderly patients with hypertension: results of 24-hour ambulatory blood pressure monitoring. $A m \mathcal{F}$ Med 1991;90:198-205.

36 Johnston CI. Angiotensin converting enzyme inhibitors. In: Robertson JIS, Nicholls MG, eds. The reninIn: Robertson JIS, Nicholls MG, eds. The renin-
angiotensin system. Vol 2. London: Gower, 1993: angiotensin

37 Conway J, Coats AJS, Bird R. Lisinopril and enalapril in essential hypertension: a comparative study using ambulatory monitoring. If Hum Hypertens 1990;4: 235-9.

38 Townsend RR, Holland OB. Combination of converting enzyme inhibitor with diuretic for the treatment of hypertension. Arch Intern Med 1990;150:1175-83.

39 Andrén L, Weiner L, Svensson A, Hansson L. Enalapril with either a "very low" or "low" dose of hydrochlorothiazide is equally effective in essential hypertension: a double-blind study in 100 hypertensive patients. $\mathcal{F}$ Hypertens 1983;1 (suppl 2):384-6.

40 Atkinson AB, Lever AF, Brown JJ, Robertson JIS. Combined treatment of severe intractable hypertension with captopril and diuretic. Lancet 1980;ii:105-8.

41 White NJ, Rajagopalan B, Yahaya HK, Ledingham JGG. Captopril and frusemide in severe drug-resistant hypertension. Lancet 1980;ii:108-10.

42 Singh BN, Hollenberg NK, Poole-Wilson PA, Robertson JIS. Diuretic-induced potassium and magnesium deficiency: relation to drug-induced QT prolongation, cardiac arrhythmias and sudden death. $\mathcal{f}$ Hypertens cardiac arrhythmias

43 Cappucio FP, MacGregor GA. Moderate potassium supplementation in hypertension: how useful? Fifth supplementation in hypertension: how useful? Fifth European meetin

44 Pickering TG. The use of angiotensin converting enzyme inhibitors in combination with other antihypertensive agents. Am f Hypertens 1991;4(suppl):73-8.

45 Brown JJ, Fraser R, Lever AF, et al. Raised plasma angiotensin II and aldosterone during dietary sodium restriction in man. Lancet 1972;ii:1106-7.

46 MacGregor GA, Marlxandu ND, Singer DRJ, et al. Moderate sodium restriction with angiotensin converting enzyme inhibitor in essential hypertension: a double-blind study. BMF 1987;294:531-4.

47 Conway J, Cruickshank J. Beta adrenoceptor blockers and the renin-angiotensin system. In: Robertson JIS, Nicholls MG, eds. The renin-angiotensin system. Vol 2 . London: Gower, 1993: 84.1-9.

48 Wing LMH, Chalmers JP, West MJ, et al. Enalapril and atenolol in hypertension: attenuation of hypotensive effect in com

49 MacGregor GA, Markandu ND, Smith SJ, et al. Captopril: contrasting effects of adding hydrochlorothiazide, propranolol, or nifedipine. $\mathcal{f}$ Cardiovasc Pharthiazide, propranolol, or nife

50 Staessen J, Fagard R, Lijnen P, et al. Double-blind comparison between propranolol and bendroflumethiacomparison between propranolol and bendroflumethiazide in captopril-treated resistan

51 Belz GG, Breithaupt K, Erb K, et al. Influence of the converting enzyme inhibitor cilazapril and the betablocker propranolol and their combination on haemodynamics in hypertension $f$ Hypertens 1989 7:817-24.

52 Hansson L. Lisinopril combined with atenolol for the treatment of hypertension. $f$ Cardiovasc Pharmacol 1991;18:457-61.

53 Bevan ES, Pringle SD, Waller PC, et al. Comparison of captopril, hydralazine and nifedipine as third drug in hypertensive patients. F Hum Hypertens 1993;7:83-8.
McAreavey D, Ramsay LE, Latham L, et al. "Third drug" trial: comparative study of antihypertensive agents added to treatment when blood pressure remains uncontrolled by a beta-blocker plus thiazide diuretic. BMF 1984;288:106-11.

55 Englert RG, Marsberger H. A single-blind study of doxazosin in the treatment of hypertension when added to non-responders to angiotensin-converting enzyme inhibitor therapy. Am Heart $f$ 1988;116:1826-32.

56 Lavezzaro G, Ladetto PE, Valente $M$, et al. Ketanserin and captopril interaction in the treatment of essential hypertensives. Cardiovascular Drugs and Therapy 1990; 4:119-22.

57 Celentano A, Galderisi M, Mossetti G, et al. Ketanserin in elderly hypertension: comparison and combination in elderly hypertension: comparison and combination system, hypertension, and serotonin antagonists. Dordrecht: system, hypertension, and
Kluwer, 1990:149-53.

58 Eggertsen R, Svensson A, Dahlöf B, Hansson L. Additive effect of isradipine in combination with captopril in hypertensive patients. Am F Med 1989;86:124-6.

59 Morgan T, Anderson A, Hopper J. Enalapril and nifedipine in essential hypertension: synergism of the hypotensive effects in combination. Clin Exp Hypertens [A] 1988;10:779-89.

60 Guazzi MD, DeCesare N, Galli C, et al. Calcium-channel blockade with nifedipine and angiotensin-converting enzyme inhibition with captopril in the therapy of patients with se
$1984 ; 70: 279-84$

61 Heagerty AM, Oldham AA, Barnes SJ. Angiotensinconverting enzyme inhibitors and resistance arterial structure. In: Robertson JIS, Nicholls MG, eds. The renin-angiotensin system. Vol 2. London: Gower, 1993:96.1-8.

62 Drexler $\mathrm{H}$. Endothelial dysfunction in heart failure and potential for reversal by ACE inhibition. Br Heart $\mathcal{f}$ 1994;72(suppl): 11-14.

63 Squire IB, Reid JL. Interactions between the reninangiotensin system and the autonomic nervous system.
In: Robertson JIS, Nicholls MG, eds. The reninangiotensin system. Vol 1. London: Gower, 1993: angiotensin
$37.1-16$.

64 Cleland JGF, Dargie HJ, Hodsman GP, et al. Captopril in heart failure: a double-blind controlled trial. Br Heart $\mathcal{F}$ 1984;52:530-5.

65 Cleland JGF, Dargie HJ, Ball SG, et al. Effects of enalapril in heart failure: a double-blind study of exercise performance, renal function, hormones, and metabolic state. Br Heart f 1985;54:305-12.

66 Hodsman GP, Brown JJ, Cumming AMM, et al. Enalapril in the treatment of hypertension with renal artery stenosis: changes in blood pressure, renin, angiotensin I and II, renal function, and body composition. $A m \mathcal{F} \mathrm{Med}$ 1984;77(2A):52-60.

67 Robertson JIS. Left ventricular, large arterial, and resistance arterial changes, the J-curve, and antiplatelet agents. Curr Opin Cardiol 1989;4:662-671.

68 Hachamovitch R, Strom JA, Sonnenblick EH, Frishman WH. Left ventricular hypertrophy in hypertension and the effects of antihypertensive drug therapy. Curr Probl Cardiol 1988;13:369-422.
the effects of antihypertent

69 Cruickshank JM, Lewis J, Moore V, Dodd C. Reversibility of left ventricular hypertrophy by differing types of antiof left ventricular hypertrophy by differing types of anti-
hypertensive therapy. $¥$ Hum Hypertens 1992;6:85-90.

70 Dahlöf B, Pennert K, Hansson L. Reversibility of left ventricular hypertrophy in hypertensive patients: a
metaanalysis of 109 treatment studies. Am $\mathscr{f}$ Hypertens metaanalysis of

71 Richards AM, Nicholls MG, Crozier IG. Role of ACE inhibitors in hypertension with left ventricula hypertrophy. Br Heart f 1994;72(3)(suppl):S24-32.

72 Safar ME, Levy BI. Angiotensin-converting enzyme inhibitors and large arterial structure and function. In: Robertson JIS, Nicholls MG, eds. The renin-angiotensin system. Vol 2. London: Gower, 1993:95.1-9.

73 Gavras I, Gavras H. Angiotensin II-possible adverse effects on arteries, heart, brain, and kidney: experimental, clinical, and epidemiological evidence. In: Robertson JIS, Nicholls MG, eds. The renin-angiotensin system. Vol 1. London: Gower, 1993:40.1-11.

74 Alderman $\mathrm{MH}$, Madhaven S, Ooi WL, et al. Association of the renin-sodium profile with the risk of myocardial
infarction in patients with hypertension. $N$ Engl f Med 1991;324:1098-104.

75 Meade TW, Cooper JA, Peart WS. Plasma renin activity and ischemic heart disease. $N$ Engl f Med 1993; 329:616-9.

76 Alderman $\mathrm{MH}$. Which antihypertensive drugs first-and why! fAMA 1992;267:2786-7.

77 Fletcher AE, Dollery CT. Side effects associated with Fletcher AE, Dollery CT. Side effects associated with Robertson JIS, Nicholls MG, eds. The renin-angiotensin system. Vol 2. London: Gower, 1993:99.1-15.

78 Callender JS, Hodsman GP, Hutcheson MJ, et al. Mood changes during captopril therapy for hypertension: a changes during captopril therapy for hypertension:
double-blind pilot study. Hypertension 1983;5(suppl III): $90-2$.

79 Dahlöf B, Andrén L, Eggertsen R, et al. Potentiation of the antihypertensive effect of enalapril by randomized addition of different doses of hydrochlorothiazide. $\mathscr{F}$ Hypertens 1985;3: (suppl 3):483-6.

80 Olajide D, Lader M. Psychotropic effect of enalapril maleate in normal volunteers. Psychopharmacology
1985;86:374-6. 
81 Lichter I, Richardson PJ, Wyke MA. Differential effects of atenolol and enalapril on memory during treatment for essential hypertension. Br f Clin Pharmacol 1986; 21:641-5.

82 Os I, Bratland B, Dahlöf B, et al. Lisinopril or nifedipine in essential hypertension? A Norwegian multicentre study on efficacy, tolerability, and quality of life in 828 patients. F Hypertens 1991;9:1097-104.

83 Steiner S, Friedhoff A, Wilson B, et al. Antihypertensive therapy and quality of life: a comparison of ateno therapy and quality of life: a comparison of atenolo captopril, enalapril and propranolol. F Hum Hypertens
1990;4:217-25.

84 Fletcher AE, Bulpitt CJ, Hawkins CM, et al. Quality of life on antihypertensive therapy: a randomized double-blind on antihypertensive therapy: a randomized double-blind
controlled trial of captopril and atenolol. $\mathcal{f}$ Hypertens

85 Testa MA, Anderson RB, Nackley JF, et al. Quality of life and antihypertensive therapy in men: a comparison of captopril with enalapril. $N$ Engl f $\mathrm{Med}$ 1993;328: $907-13$

86 Santanello NC, Gress H, Heyse JF. Captopril, enalapril and quality of life. $N$ Engl fु Med 1993;329:505.

87 Fletcher AE. Captopril, enalapril and quality of life. $N$ Engl f Med 1993;329:505-6.

88 Ware JE. Captopril, enalapril and quality of life. $N$ Engl $\mathcal{F}$ Med 1993;329:506.

89 Testa MA, Hollenberg NK. Captopril, enalapril and quality of life. $N$ Engl F Med 1993;329:507.

90 Hodsman GP, Isles CG, Murray GD, et al. Factors related to first dose hypotensive effect of captopril: prediction and treatment. BMF 1983;286:832-4.

91 Cleland JGF, Dargie HJ, McAlpine $\mathrm{H}$, et al. Severe hypotension after first dose of enalapril in heart failure. BMF 1985;291:1309-12

92 Robertson JIS. Intrarenal variations in renin content: physiological and pathophysiological patterns in relation to single nephron function. In: Robertson JIS, Nicholls, to single nephron function. In: Robertson JiS, Nicholls, Gower, 1993:21.1-10

93 Bennett T, Gardiner SM. Differential effects of various converting-enzyme inhibitors. In: Robertson JIS converting-enzyme inhibitors. In: Robertson JIS,
Nicholls MG, eds. The renin-angiotensin system. Vol 2 . London: Gower, 1993:98.1-16.

94 Havelka J, Vetter H, Studer A, et al. Acute and chronic effects of the angiotensin-converting enzyme inhibito captopril in severe hypertension. $\mathrm{Am} f$ Cardiol

1982;49:1467-73.
95 Robertson JIS. Angiotensin-converting enzyme inhibitors and Raynaud's phenomenon. In: Robertson JIS
Nicholls MG, eds. The renin-angiotensin system. Vol 2 London: Gower, 1993:97.1-2.

96 Hormigo A, Alves A. Peripheral neuropathy in a patient receiving enalapril. BMf 1992;305:1332.

97 Robertson JIS. Renin and the nephrotic syndrome. In: Robertson JIS, Nicholls MG, eds. The renin-angiotensin system. Vol 2. London: Gower, 1993:58.1-8.

98 Webb DJ, Atkinson AB. Enalapril following captoprilinduced nephrotic syndrome. Scott Med f 1986; 31:30-2.

99 August $P$. The renin-angiotensin-aldosterone system in hypertension in human pregnancy. In: Robertson JIS,

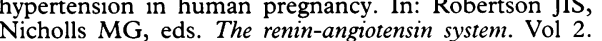
Nicholls MG, eds. The renin-angio

100 Dollery CT, Boobis AR, Burley D, et al, eds. Therapeutic drugs. Edinburgh: Churchill Livingstone, 1991.

101 Guidelines Sub-Committee. 1993 guidelines for the management of hypertension: memorandum from a World Health Organization/International Society of World Health Organization/International Society

102 Pickering GW. Normotension and hypertension: the mysterious viability of the false. Am $\mathcal{F}$ Med 1978; 65:561-3

103 Skrabanek P. Nonsensus consensus. Lancet 1990;335: 1446-7.

104 Robertson JIS. The 1993 guidelines for the treatment of hypertension: a critical commentary. Cardiovascular Drugs and Therapy 1994;8:91-8.

105 Muntzel M, Drüecke T. A comprehensive review of the salt and blood pressure relationship. Am 7 Hypertens 1992;5(suppl):1-42.

106 Ruppert M, Overlack A, Kolloch R, et al. Neurohumoral and metabolic effects of severe and moderate salt restriction in non-obese normotensive adults. $\mathcal{f}$ Hypertens 1993;11:743-9.

107 Alderman $\mathrm{MH}$, Cohen $\mathrm{H}$, Madhaven $\mathrm{S}$. Low urinary sodium and increased myocardial infarction and total cardiovascular disease among treated hypertensives. $\mathcal{f}$ cardiovascular disease among tre

108 De Wardener HE, Kaplan NM. On the assertion that a moderate restriction of sodium intake may have
adverse health effects. Am $\mathcal{f}$ Hypertens 1993;6: $810-4$.

109 Staessen J, Amery A, Birkenhäger W, et al. Is a high serum cholesterol associated with longer survival in elderly hypertensives? f Hyper

110 Medical Research Council Working Party. MRC trial of treatment of hypertension in older adults: principal results. $B M f$ 1992;304:405-12. 